\title{
The Possibility of Digital Preschool
}

\author{
Himmah Taulany, Syifa Fauziah \\ Ngudi Waluyo University,Ungaran Indonesia \\ e-mail: taulany27@gmail.com
}

\begin{abstract}
The digital world is an ongoing reality that happened after 4.0 industrial revolution began. Procedures which is involving the digital world has been part of daily lives. It also has an impact in early childhood education. Is it possible for early childhood education to fully apply digital device in the process? Such an issue is tempting to be answered and explored in scientific research scope. This article is purposed to investigate and analyze research writing and non-research writing that encompassing in digital pre-school. From various literature, it can be concluded that digital pre-school hasn't been fully employed. Digital devices are still used as complementary for conventional non-digital learning media. Although, facilities, infrastructure, and also support to fully accomplish digital pre-school in several countries, along with its citizen's need, has increased possibility to apply digital pre-school in early childhood education. There will be also a negative trait of digital pre-school besides its benefits. It requires a contribution from every parents, schools, government, and society in overall to achieve good, safe, and beneficial digital pre-school for early childhood development.
\end{abstract}

Keywords: Digital preschool, early chilhood edudation

\section{INTRODUCTION}

Is it possible that digital preschool be implemented? This question arises along with the increasingly widespread use of information technology software, such as a smartphone, laptop, tablet and so on. A digital world has filled the diversity of life and has made a digital preschool be possible. The digital age as the new ecosystem of the world, as a result of the industrial revolution 4.0, makes life joints become digital. Humans and data coexist and interact with digital technology devices.

Bob Gordon of Northwestern University, as quoted Prasetiantono (2018), wrote that there had been three industrial revolutions before. First, the invention of steam engines and trains (1750-1830). Second, the invention of electricity, communications, chemical and oil (1870-1900). Third, the invention of computers, internet and mobile phones (1960 to present). Another version states that the third industrial revolution began in 1969 , with the advent of information technology and automation machinery. The advanced technologies include artificial intelligence (AI), e-commerce, big data, fintech, shared economies, until the use of robots. The term 4.0 industry was first introduced at the Hannover Fair 2011, which is characterized by a digital revolution.Bob Gordon of Northwestern University, as quoted Prasetiantono (2018), wrote that there had been three industrial revolutions before. First, the invention of steam engines and trains (1750-1830). Second, the invention of electricity,

The influence of the digital world as a consequence of this 4.0 industrial revolution also affects the world of education, including early childhood education. Various research and nonresearch articles raised the topic of the digital world associated with early childhood. Each study can be categorized based on the location setting i.e. home (O'Hara, 2011; Stephen, 2013; Marsh, 2015), school (Wu et al., 2014; Johnson, 2010; Fridberg et al., 2017; Kirova et. al, 2018), home and school (Lien Foundation, 2011, Thorpe, 2015). All the articles 
indicated that the use of digital devices by early childhood both at home and at school brings to the possibility of implementing digital preschool. To what extent does the digital media influence early childhood education and is digital preschool possible? This will be the fundamental question that will be discussed in this article.

The influence of the digital world as a consequence of this 4.0 industrial revolution also affects the world of education, including early childhood education. Various research and nonresearch articles raised the topic of the digital

\section{LITERATURE REVIEW}

Before further review about the possibility of implementing digital preschool, it is good to first explore the notion of digital preschool. There are several notions of digital preschool according to the literature study. The existence of digital preschool can be a group of children who are in a location and then learn together with a professional educator through the screen and connected online. This is similar to the situations that exist, like a teleconference that is now mostly done by adults. It could also be done by the teacher who provides online learning, while the child remains at home accompanied by parents/other adults, and then follow the direction of the instructor. This sense is more accurately referred to as a virtual preschool (Herold, 2015). The condition of early childhood education is more like homeschooling but uses guidance from experts packaged in the digital curriculum.

The meaning taken in this article is a preschool that uses the full digital device in the learning process. From research and non-research articles, digital preschool has been done in several countries. For example, in Singapore with IngoT Preschool (Lien Foundation, 2011). This school in its pressrelease mentioned the use of digital devices in most of its activities. The curriculum for early childhood also involves computer devices, tablets filled with digital-based learning programs. School administration and support activities like parenting also use phones, laptops and social media networks. Reporting a child development in both positive and existing issues can be done immediately to parents. This makes the exchange of information between schools and parents better.

Another side of the use of digital devices, such as the internet, is the Thorpe (2015) study, which examined the use of web search by Australian preschoolers in their class practice $(\mathrm{N}=131)$. The availability of digital technologies that support the Internet and the contribution of teacher demographic characteristics, convenience with digital technology, and the beliefs about its usage were assessed. Internet-enabled technology was available in 53\% (n = 69) classrooms. Inside this classroom, teachers' age and belief predicted a web search practice. While comfortable with the digital access of knowledge in their daily lives, teachers reported less convenient with web search in the context of their classroom practices. The findings identified the provision of technologies that support the internet and professional development as measures to support the effective inclusion and confident of web search in the classroom. Such action was necessary to harmonize with the national policy document defining the acquisition of digital literacy as the goal and affirming digital access to knowledge as an equity issue.

Another literature of Kirova et.al (2018) presented the findings of a four-month qualitative, intrinsic case study that examined the 25 experiences and technologies of multi-literacy of preschoolers in the context of their home and classes. This study paid a particular attention to the role of adult and peers scaffolding. This article briefly described the teacher scaffolding process and discusses in detail the example that emerged.

The most important things are two video series that show a more capable counterpart using strategies and approaches to scaffold his colleagues in creating digital literacy texts. Based on the data, researchers argued that more capable peers can be an important source to address the multi-literacy experiences of children in the context of the preschool classroom. The findings of these study offered teachers and educational researchers an insight into how young people can be engaged and tailored by teachers and peers in their multi-literacy practices before formal schooling.

Research about the digital world is also done by Stephen et.al (2013). This article is about the ways young people engage with toys and technology resources at home and, in particular, the way in which the family context makes a difference to the involvement of young people with this technology. The results showed that all families support the use of resources by their children, but the evidence showed clearly that the child's experience was different in each home. The article goes on to 
present evidence that four dimensions of family context made a difference to children's involvement with toys and home technology resources. In order to understand children's experiences with home technology, the knowledge of the different family contexts in which they are involved with the resources turns out to be an influential factor.

Another research that had been conducted is by Johnson (2010) on thirty-eight children in first and second grade by completing a 10-item assessment scale on internet use at home and school. Results show that, in general, more children used the internet at school than at home but home use was more often considered fun. Three emerging internet usage patterns showed three types of young users: home-based users indicated widespread, comprehensive, and home-friendly internet usage coupled with limited and less enjoyable use of the internet in schools; school-oriented information seekers were reported mainly to visit websites, both at home and at school, but access to school is preferred; and school-oriented communicators showed primarily using email, both at home and at school, but school use is preferred. The implications for internet literacy in young students are also discussed.

Marsh (2010) stated in his research that the virtual world for children was becoming more popular, but there are accounts about the use of children from this world. Young people were spending an increasing amount of online time as technology continues to create significant changes in social and cultural practices in the 21 st century. Some children's online interactions can be categorized as fun games; However, play and technology are often positioned as opposition. This article provides an overview of two virtual worlds that were currently targeted at young children and refers to the primary use survey of the cyberspace of children to identify the nature of play in this environment. One hundred and seventy-five children aged 5-11 completed an online survey and 15 took part in group interviews where their cyberspace use was explored. This article focuses on data relating to 17 children aged five to seven who use the virtual world. The findings show that cyberspace offered these children various opportunities to play and that the type of game in which they were involved is closely related to playing 'offline'. Implications for early-year educators were also considered.

Research conducted by Fleer (2018) found that although technology has been used in inclusive education for a long time, there are relatively few historical-cultural studies that had focused on the pedagogical framework of digital tablets for preschoolers with additional visual needs. This article seeks to contribute to filling this void in the literature by presenting the findings of a case study of a child with visual impairment using digital tablet technology to conceptually rather than visually navigate the way around his neighborhood. The study involved the observation of a 4.1-year-old boy with albinism. Observations were digitally recorded over a 3-week period (74 hours) at home and in preschool. Vygotsky's inclusion theory informed the research design, and the concept of a social development situation guided detailed analysis. The findings suggest that contrary to the traditional conceptualization of technology as compensation, digital tablet technology provides new relationships for children sitting in social systems, framing inclusive practices in preschool and home environments. This study has been contributing to the development of a new understanding of inclusive pedagogy for the digital environment in early childhood settings.

Kelly (2013) conducted research on keeping the social interaction within families between generations with the help of internet information technology. This article discusses a small-scale study exploring how members of single families living in Australia and the UK use remote technology to develop and maintain crossgenerational and distance family relationships. What was interesting was the way in which Skype computer software was mediated to develop intersubjectivity between a 4-year-old girl and her grandparents. Meetings filmed, transcribed and encoded; participants were interviewed and asked to keep a reflective diary. The analysis shows that all adults engage children's interactions to maintain communication and help them negotiate the meaning with their grandparents as virtual partners, but it also takes a leadership role by adjusting the media's ability to incorporate it in the game in a creative way.

O'Hara (2011) conducted a small-scale research focusing on the information experience and communication technology (ICT) of children reported at home and the role of parents in providing opportunities, recognition, and technological support. Children from involved parents are all enrolled in the nursery class and the reception (aged 4-5 years) in two settings (hereinafter referred to as 
Stafford School and Hill School). The term home was used here to indicate any context in the lives of children outside the school/nursery environment while the ICT interpretation is also equally broad and inclusive and included any technology related to the handling and transmission of electronic information and/or its use in controlling the operation of the machine and other devices. In this context, therefore, ICT will cover things like phone, television, video, audio recorder, CD and DVD player, CD-ROM, programmable toy, game console, radio and, of course, computer. The study found that differences in the incidence and availability of ICT in children's homes can sometimes be subtle and are the result of a number of factors. Children may have "accesses" to certain technologies because they are present in their home environment but this did not mean that children could always and/or be allowed to 'use' the technology. Young people already have the knowledge and competence of ICTs when they arrive at nursery and reception partly as a result of different levels of parental intervention and modelling and are in the process of acquiring new knowledge, skills and attitudes. The study also argued that parental involvement with ICT was often characterized by conscious but sometimes uncertain to limit the opportunities and accesses to ICT in the best interests that children feel.

Edwards (2014) gave his idea of a 'contemporary' game in relation to existing ideas about children's games, learning, and development from a sociocultural perspective. The need to think about the nature of contemporary games was seen as a response to the argument that showed that the quality of children's games had declined as their access to digital technology, digital media and consumer-based products were increasing. In this article, the idea of a digital-consumerist context is explored as a way of thinking about how this increased availability of technology, media and products had evolved and assembled to create a specialized site for development that were connected with existing understanding of play as a leading activity and the role of adult play in development children. Rather than positioning technology, media and products as the cause of deficiencies in children's games, it was suggested that the digitalconsumerist context promotes a form of direct cultural participation for young people (ages 0-8 years) with the potential to embody different ways of participating in the continuum of digital experience to non-digital. These experiences are framed as a form of cultural relationship parallel to existing socio-cultural stories as a process of cultural interpretation.

Vittrup, et.al (2014) conducted a research in the US by surveying the attitudes and perceptions of parents about the knowledge and involvement of their children with a variety of media technologies, as well as to explore the actual knowledge and experience of children with these tools. Overall, parents showed positive attitudes toward the media, as long as they believed that media exposure was vital to the development of children, although there was still debate about how long it would take for children to use the media. This indicated that digital media had penetrated widely and also gave an influence to the education of early childhood.

Fridberg et. al (2017) reported a project aimed at broadening the current understanding of how emerging technologies, i.e. tablets, could be used in preschool to support the collaborative learning of real-life science phenomena. Potential tablets to support the science-based learning of collaborative inquiry and reflective thinking in preschools were investigated through analysis of teacher-led activities in science, including children making timelapse photography and slow-motion films. Qualitative analysis of verbal communication during different learning contexts raised a number of categories that differentiate and identify different discussion themes. In this study, groups of children work with water change phases. Researchers reported an increase and focus on reasoning about this science phenomenon in situations where film time-lapse was used to stimulate memory. Furthermore, the results show that children communicated in a more advanced way about the phenomenon, and they were more likely to focus on problem-solving when active in experimentation or inhibition produces context.

Wu et.al (2014) stated in his research that young people use digital technology devices (DT) anytime and anywhere, especially with the invention of smartphones and the replacement of desktop computers with digital tablets. Although research had shown that parents play an important role in fostering and supporting the maturity and development decisions of pre-school children about the use of Digital Technology (DT), and in protecting them from potential risks due to excessive DT exposure, there is limited research conducted in Hong Kong which focuses on parent-child. This study has three objectives: 1) to explore the use of 
parents of DTs with their preschoolers; 2) to identify DT content related to child behavior issues, and 3) to investigate the relationship between the approach adopted by parents to control the use of childhood DT and preschool related preschool problems.

Marsh (2015) reported a study exploring the digital literacy of young children at home. The purpose of this study was to identify a variety of digital literacy practices in which children were engaged at home and to explore how this is embedded in family life and involves family members. This further showed that the digitalworld was already a part of life today.

\section{FINDINGS AND DISCUSSION}

Early childhood requires concrete and real learning. The uniqueness of these characteristics makes early childhood education requires interesting learning media and fostering early childhood attention to learn. According to media theory, the more senses that are stimulated the easier it will be for the child to understand a material. Digital media has the ability to attract children to learn or interact with the media. Active moving view, interesting sound and color, make the child more comfortable to occupy themselves with digital media. The more views that attract children the more time children spend playing with digital media.

The influence of the environment around the child also influences the development of early childhood, including the use of digital devices. The environment around the child who also uses a lot of digital media such as a smartphone, laptop or tablet make children think that it is also reasonable for their use. Parents or adults around them often interact more with digital media than interact with people around them. We can see at the social gatherings today, people who do not pay attention to the surrounding environment and instead pay more attention to digital media devices.

This of course also affects the children. They are formed into individuals who are comfortable with their own digital world. This is a negative effect that can be caused by the use of digital media that does not pay attention to the balance of interaction with other humans. Though man is a social creature that requires interaction with each other. It is true that in digital media there is also an interaction between media users such as in social media (Whatsapp, Facebook, Twitter, and others).
However, a physical touch, direct energy exchange with direct conversation, has a different effect on one's mental health. So does with early childhood. They need a direct physical touch that can help the development of the soul to become healthier and balanced.

Digital preschools that do not pay attention to the need for direct interaction balance are certainly not appropriate to the needs of young children. For that need a kind of additional menu that is still a meeting directly at certain times. A better digital preschool concept is to keep parents engaged in educating children. The existence of teachers is not only limited to providing instructions but still accompany children as well as parents. Social relationships between children can be established by interaction online and by meeting physically within a specified time.

The existence of digital media especially for early childhood does require monitoring from parents, teachers, schools, community and government as the holder of policy authority including education. The circulation of application programs that are less educational should be prohibited so as not to interfere with child development. Application programs such as animated games are widely consumed by early childhood. Harmful applications for children are now also being highlighted by the government, in Indonesia, through the Ministry of Communication and Information of the Republic of Indonesia (Kominfo) by issuing a ban on the circulation of such applications (https://www.kominfo.go.id/).

Based on the literature review, it is true that the use of digital media in learning has not been in complete. Most schools still combine digital media with conventional learning media. Digital media is used in certain lessons. Articles from Thorpe (2015) showed that not all educators were willing and able to use digital information technology such as the internet while teaching in the classroom, although the educators were in the day as well as internet users. In this article, it could be found that although the facilities and infrastructure of school information technology have been possible, there were still less comfortable educators use it in classroom learning. This meant that teachers were still using conventional media and did not optimize digital devices in the form of internet that was available.

As an example of preschool in Indonesia using digital media along with conventional media is KB / TK Oasis Kids Semarang City Central Java 
Province. This school holds English lessons for learners with android devices and application of English learning program for early childhood (Fitrianingtyas, 2013).

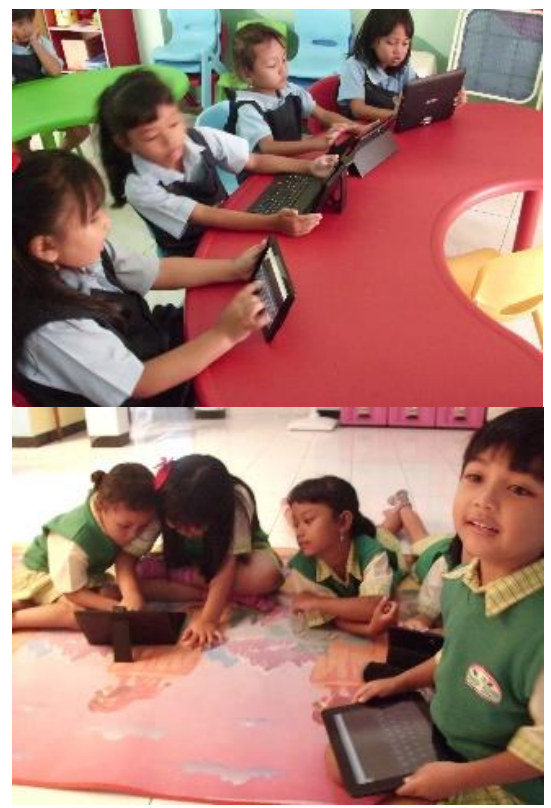

Fig 1. Children are using tablets of English vocabulary recognition program.

The use of digital media for early childhood both at home and school use provides many benefits. Fleer (2018) pointed out in his article on the benefits of pedagogical digital tablets for preschoolers with additional visual needs. Similarly, Kelly (2013) which showed that technology could help to maintain emotional social relationships in the family and between generations. Of course, digital preschool also has the same effect in maintaining the emotional social relations of early childhood both between friends and with adults around it, but still needed direct learning by physical contact in order to stay balanced. Positive benefits of digital media such as tablets can also help young children to understand natural phenomena that are hard to observe if not with technological help (Fridberg et al, 2017).

However, the positive benefits are apparently coupled with the negative effects of digital media. Based on the study of literacy can be seen some negative effects of digital media that are, if not accompanied by direct physical interaction, the child's emotional-social development becomes less balanced. Also need guidance and direction from parents, teachers and adults around the child while playing with digital media in order to stay awake from the application of programs that are less good for the development of children. Time spent by children in playing digital media can also have a negative impact on health for too long, such as the results of the Vittrup survey, et.al (2014).

Edwards' idea (2014) can also be one example of a synergy between traditional or traditional games that offer a lot of stimulation of all the senses of early childhood with digital media limited to fewer physical movements. Practitioners of the gamemakers for education began to include something that can stimulate aspects of early childhood development such as aspects of religious and moral values, language, motor and physical art, in addition to cognitive aspects that have been more dominant.

\section{CONCLUSION}

Based on the description of the findings and discussion in this article, it can be concluded that digital preschool is possible to be realized in the world of early childhood education. Challenges and world conditions are increasingly dominated by digital, making the direction of education even more digital including early childhood education. However, it still requires the wisdom of parents, teachers, principals, and providers of early childhood education, government stakeholders of educational policy and society as a whole to oversee the education of digital preschool good, safe and beneficial for early childhood development.

\section{REFERENCES}

[1] Edwards. S. (2014). Towards Contemporary Play: Sociocultural Theory and The DigitalConsumerist Context. Journal of Early Childhood Research. Available from http://journals.sagepub.com/doi/abs/10.1177/14 $76718 X 14538596$ (accessed 10 Juli 2018).

[2] Fitrianingtyas, A. (2013). Upaya Meningkatkan Kemampuan Bahasa Inggris melalui Media Baca Kata Berbasis Android. Skripsi. Program Studi Pendidikan Guru Pendidikan Anak Usia Dini. IKIP PGRI Semarang.

[3] Fleer, M. (2018). Digital Bridges Between Home and Preschool: Theorising Conceptually Inclusive Practice in Digital Environments. Journal of Early Childhood Research. Available from https://link.springer.com/chapter/10.1007/978981-10-6484-5_3. (accessed 10th July 2018).

[4] Fridberg, M. Thulin, S. Redfors, A. (2017) Preschool children's Collaborative Science Learning Scaffolded by Tablets. Research in Science Education. Available from 
https://link.springer.com/article/10.1007/s11165 -016-9596-9. (accessed 9th July 2018).

[5] Herold, B. (2015). Virtual Preschool: Yes, That's Now a Real Option.Digital Education. Available from http://blogs.edweek.org/edweek/DigitalEducatio n/2015/02/virtual_preschool_now_real_option.h tml. (accessed 10th July 2018)

[6] Johnson, G.M. (2010). Young children's Internet use at home and school: Patterns and profiles. Journal of Early Childhood Research. Available from http://journals.sagepub.com/doi/abs/10.1177/14 76718X10379783. (accessed 9th July 2018)

[7] Kelly, C. (2013). 'Let's do some jumping together': Intergenerational participation in the use of remote technology to co-construct social relations over distance. Journal of Early Childhood Research. Available from http://journals.sagepub.com/doi/abs/10.1177/14 76718X12468121. (accessed 7th July 2018)

[8] Kementerian Komunikasi dan Informasi Republik Indonesia. (2018). Program Prioritas: Sesuai Rencana Strategis Kementerian Komunikasi dan Informasi Republik Indonesia. Available from https://www.kominfo.go.id/. (accessed 29th July 2018)

[9] Kirova, A.Jamison, M.N.(2018). Peer scaffolding techniques and approaches in preschool children's multiliteracy practices with iPads. Journal of Early Childhood Research. Available from http://journals.sagepub.com/doi/abs/10.1177/14 76718X18775762. (accessed 9th July 2018)

[10] Lien Foundation. (2011). The Digital Preschool: a prototype for tomorrow's early education. IngoT http://www.lienfoundation.org/project1 ?revision_id $=313$

[11] Marsh, J. (2010). Young Children's Play in Online Virtual Worlds. Journal of Early Childhood Research. Available from http://journals.sagepub.com/doi/abs/10.1177/14 76718X09345406. (accessed 10th July 2018).
[12] Marsh. J., Hannon. P, \& Lewis. M. (2015) Young children's Initiation into Family Literacy Practices in The Digital Age. Journal of Early Childhood Research. Available from http://journals.sagepub.com/doi/abs/10.1177/14 $76718 X 15582095$ (accessed 10th July 2018)

[13] O'Hara, M. (2011). Young children's ICT experiences in the home: Some parental perspectives. Journal of Early Childhood Research. Available from http://journals.sagepub.com/doi/abs/10.1177/14 76718X10389145. (accessed 9th July 2018)

[14] Prasetiantono, A. T. (2018). Revolusi Industri 4.0. Pusat Studi Ekonomi dan Kebijakan Publik UGM. Available from https://psekp.ugm.ac.id/2018/04/10/revolusiindustri-4-0/. (accessed 29th July 2018)

[15] Stephen, C. Stevenson, O. Adey, C. (2013). Young children engaging with technologies at home: The influence of family context. Journal of Early Childhood Research. Available from http://journals.sagepub.com/doi/full/10.1177/14 76718X12466215. (accessed 9th July 018).

[16] Thorpe, K. Hansen, J. Danby, S. Filzah, M.Z. Grant, S. Houen, S. Davidson, C. Givend, L.M. (2015). Digital Access to Knowledge in The Preschool Classroom: Reports from Australia. Early Childhood Research Quarterly. Vol.32(3):174-182. Available fromhttps://www.sciencedirect.com/science/arti cle/pii/S0885200615000393. (accessed 9th July 2018)

[17] Vittrup. B., Snider.S., Rose. K. (2014). Parental Perceptions of the Role of Media and Technology In Their Young Children's Lives. Journal of Early Childhood Research. Available from http://journals.sagepub.com/doi/abs/10.1177/14 $76718 X 14523749$ (accessed 10th July 2018)

[18] Wu, C.ST. Fowler, C. Lam, W.Y.Y.I. Wong, H.T. Charmaine Hei Man Wong, C.H.M. Loke, A.Y.L. (2014). Parenting approaches and digital technology use of preschool age children in a Chinese community. Italian Journal of Pediatrics 2014 (40)44. Available from http://www.ijponline.net/content/40/1/44 